\title{
Ketamine Treatment for Refractory Anxiety: A systematic review
}

\author{
Jamie Tully ${ }^{1}$, Amelia Dahlén ${ }^{2}$, Connor Haggarty ${ }^{3}$, Helgi Schiöth² ${ }^{2}$ and Samantha Brooks ${ }^{4}$ \\ ${ }^{1}$ University of Exeter College of Life and Environmental Sciences \\ ${ }^{2}$ Uppsala University \\ ${ }^{3}$ Linköping University \\ ${ }^{4}$ Liverpool John Moores University
}

November 1, 2021

\begin{abstract}
There is a growing interest in the psychiatric properties of the dissociative anesthetic ketamine, as single doses have been shown to have fast-acting mood-enhancing and anxiolytic effects, which persist for up to a week after the main psychoactive symptoms have diminished. Therefore, ketamine poses potential beneficial effects in patients with refractory anxiety disorders, where other conventional anxiolytics have been ineffective. Ketamine is a non-competitive antagonist of the N-methyl-D-aspartate (NMDA) glutamate receptor, which underlies its induction of pain relief and anaesthesia. However, the role of NMDA receptors in anxiety reduction is still relatively unknown. To fill this paucity in the literature, this systematic review assesses the evidence that ketamine significantly reduces refractory anxiety and discusses to what extent this may be mediated by NMDA receptor antagonism. We highlight the temporary nature of the anxiolytic effects and discuss the high discrepancy among the study designs regarding many fundamental factors such as administration routes, complementary treatments, and other treatments.
\end{abstract}

\section{Hosted file}

The role of ketamine NMDA antagonism in refractory anxiety disorders_Final.docx available at https://authorea.com/users/443967/articles/543824-ketamine-treatment-for-refractoryanxiety-a-systematic-review

Hosted file

Consort diagram.docx available at https://authorea.com/users/443967/articles/543824-ketaminetreatment-for-refractory-anxiety-a-systematic-review

\section{Hosted file}

Ketamine pharmacology figure.docx available at https://authorea.com/users/443967/articles/ 543824-ketamine-treatment-for-refractory-anxiety-a-systematic-review

\section{Hosted file}

Systematic review table.docx available at https://authorea.com/users/443967/articles/543824ketamine-treatment-for-refractory-anxiety-a-systematic-review 